\title{
Decreased mucosal interleukin-4 (IL-4) production in gut inflammation
}

\author{
R Karttunnen, E J Breese, J A Walker-Smith, T T MacDonald
}

\begin{abstract}
Aims-To determine the prevalence of cells secreting interleukin-4 (IL-4) in the gut mucosa of children with chronic inflammatory bowel disease.

Methods-Mononuclear cells were isolated from intestinal biopsy specimens from control children $(n=10)$ and children with active inflammatory bowel disease (Crohn's disease $n=15$, ulcerative colitis $n=9$, indeterminate colitis $n=3$ ). Spontaneous IL-4 production was then measured by SPOT-enzyme linked immunosorbant assay (ELISA) using a pair of non-competing anti-IL-4 monoclonal antibodies. The percentage of $T$ cells in the isolated cells was also determined and the prevalence of IL-4 secreting cells calculated per $10000 \mathrm{~T}$ cells.

Results-In control children the mean number of IL-4 secreting cells was $15 \cdot 1$ per $10000 \mathrm{~T}$ cells. In Crohn's disease and ulcerative colitis the means were 5.3 and $5 \cdot 2$, respectively. In two children with indeterminate colitis numbers were also low. There was no difference in the percentage of $T$ cells in the cell preparations isolated from each patient group. The reduction of IL-4 secreting cells in patients with Crohn's disease was not caused by steroids.

Conclusions-In idiopathic inflammatory bowel disease IL-4 secreting cells are reduced in diseased mucosa.
\end{abstract}

(F Clin Pathol 1994;47:1015-1018)

There is increasing evidence that $\mathrm{T}$ cell immunity has a primary role in the pathogenesis of the chronic granulomatous inflammation in the gut mucosa of patients with Crohn's disease. Use of immunohistochemistry, polymerase chain reaction (PCR), northern blots, measurement of $T$ cell derived lymphokines in serum, and functional assays of lymphokine release shows that there seems to be an ongoing $\mathrm{T}$ cell response in the mucosa in Crohn's disease that is not detectable in ulcerative colitis. ${ }^{1-5}$ The antigens driving this response are not known. Animal models of Crohn's disease rely on the generation of $\mathrm{T}$ cell responses in the gut wall. ${ }^{6.8}$

Studies to date on $\mathrm{T}$ cell lymphokine release in the mucosa in Crohn's disease have concentrated on the measurement of interleukin-2 (IL-2) and interferon- $\gamma$. It is becoming increasingly clear, however, that these cytokines are produced mainly by Th1-type helper $T$ cells and that activated Th2-type helper $T$ cells can produce other cytokines such as IL-4 or IL-5..$^{10}$ Thus, the absence of IL-2 and interferon $-\gamma$ secreting cells in ulcerative colitis may not be due to the absence of $T$ cell activation, but to the $T$ cells releasing other cytokines (a Th2 response).

To address this question, we isolated cells from the intestinal mucosa of children with Crohn's disease, ulcerative colitis, or controls and determined whether they were secreting IL-4, using the well established enzyme linked immunosorbent SPOT (ELISPOT) assay. ${ }^{11}$

\section{Methods}

Clinical details of the patients are shown in the table. Biopsy specimens were obtained from 37 patients. Children with inflammatory bowel disease were all in the active phase of the disease. All children underwent colonoscopy because of known inflammatory bowel disease in relapse or for initial investigation (table). Of the patients with Crohn's disease receiving treatment, elemental diet had been administered for eight weeks, cyclosporin A for eight weeks, prednisolone only between six and 10 weeks, prednisolone and mesalazine between four and 20 weeks and mesalazine only for two weeks before endoscopy.

Patients with ulcerative colitis receiving treatment before endoscopy received either cyclosporin for eight weeks, prednisolone only for eight to 10 weeks, prednisolone and mesalazine for four to eight weeks, or mesalazine only for six weeks. The two patients with indeterminate colitis receiving treatment received either prednisolone for eight weeks or prednisolone and mesalazine for six weeks before endoscopic examination. Multiple biopsy specimens were taken from the terminal ileum and colon for histopathological analysis. Two biopsy specimens were also taken from a site of active inflammation (taking care to avoid ulcers) in children with endoscopically visible disease. Children with no endoscopic disease had biopsy specimens taken from the transverse colon or caecum.

The degree of inflammation in two biopsy specimens taken adjacent to those taken for measurement of IL-4 secretion was graded blind as mild, moderate, or severe by an independent histopathologist using the criteria described elsewhere. ${ }^{12}$ All biopsy specimens for histological assessment were assigned an overall inflammation score. Separate scores were given for small and large bowel as appropriate. The score ranged from $0-3$ (where 0 was normal, 1 was mild inflammation, 2 was moderate inflammation, and 3 was severely inflamed), according to the presence of ulceration, acute and chronic inflammation, crypt 
Clinical details of children from whom mucosal specimens were obtained for measurement of IL-4 secreting cells

\begin{tabular}{|c|c|c|c|c|c|c|c|}
\hline Age & $\operatorname{Sex}$ & Biopsy site & $\begin{array}{l}\text { Histological } \\
\text { score }\end{array}$ & $\begin{array}{l}\text { Disease } \\
\text { location }\end{array}$ & $\begin{array}{l}E S R \\
\text { mm/hour }\end{array}$ & $\begin{array}{l}C R P \\
m g \%\end{array}$ & Treatment \\
\hline \multicolumn{8}{|c|}{ Crohn's disease } \\
\hline 1 & $10.5 \mathrm{~F}$ & I & 3 & I & 24 & & Prednisolone/mesalazine \\
\hline 2 & $15.0 \mathrm{~F}$ & I & 3 & I & & & Elemental diet \\
\hline 3 & $14 \cdot 0 \mathrm{M}$ & I & 2 & $\mathrm{I}, \mathrm{C}$ & 27 & 5 & Nil \\
\hline 4 & $14 \cdot 2 \mathrm{M}$ & I & 2 & $\mathrm{I}, \mathrm{C}$ & 15 & 5 & Elemental diet \\
\hline 5 & $12 \cdot 3 \mathrm{~F}$ & $\mathrm{C}$ & 2 & $\mathrm{C}$ & 34 & 15 & Prednisolone/mesalazine \\
\hline 6 & $14 \cdot 4 \mathrm{M}$ & $\mathrm{C}$ & 1 & C & 44 & 55 & Mesalazine \\
\hline 7 & $14.0 \mathrm{M}$ & C & 3 & C & 26 & 42 & Prednisolone \\
\hline 8 & $14.0 \mathrm{M}$ & $\mathrm{C}$ & 2 & $\mathrm{C}$ & 16 & 52 & Nil \\
\hline 9 & $11.5 \mathrm{~F}$ & $\mathrm{C}$ & 1 & $\mathrm{C}$ & 54 & 37 & Cyclosporin A \\
\hline 10 & $11.5 \mathrm{~F}$ & C & 1 & $\mathrm{C}, \mathrm{I}$ & & 27 & Nil \\
\hline 11 & $6.8 \mathrm{~F}$ & C & 2 & $\mathrm{C}$ & & 102 & Prednisolone \\
\hline 12 & $16.4 \mathrm{M}$ & $\mathrm{C}$ & 3 & C & 55 & & Prednisolone \\
\hline 13 & $16.0 \mathrm{~F}$ & $\mathrm{C}$ & 2 & $\mathrm{C}, \mathrm{I}$ & 26 & 61 & Prednisolone/mesalazine \\
\hline 14 & $12.5 \mathrm{~F}$ & $\mathrm{C}$ & 2 & $\mathrm{C}, \mathrm{I}$ & 14 & 99 & Prednisolone/mesalazine \\
\hline 15 & $4 \cdot 8 \mathrm{~F}$ & $\mathrm{C}$ & 2 & $\mathrm{C}$ & 24 & 54 & Nil \\
\hline \multicolumn{8}{|c|}{ Ulcerative colitis } \\
\hline 16 & $8.4 \mathrm{~F}$ & C & 3 & C & 38 & 37 & Cyclosporin A \\
\hline 17 & $12 \cdot 5 \mathrm{M}$ & C & 1 & $\mathrm{C}$ & 3 & 5 & Prednisolone \\
\hline 18 & $9 \cdot 1 \mathrm{~F}$ & C & 3 & C & 34 & 51 & Prednisolone/mesalazine \\
\hline 19 & $12.8 \mathrm{~F}$ & C & 3 & $\mathrm{C}$ & 54 & 58 & Prednisolone/mesalazine \\
\hline 20 & $14 \cdot 0 \mathrm{M}$ & C & 2 & C & 6 & 10 & Prednisolone/mesalazine \\
\hline 21 & $4 \cdot 3 \mathrm{~F}$ & $\mathrm{C}$ & 1 & $\mathrm{C}$ & 5 & $<5$ & Prednisolone \\
\hline 22 & $15 \cdot 2 \mathrm{M}$ & C & 3 & C & 57 & $>115$ & Prednisolone/mesalazine \\
\hline 23 & $5 \cdot 7 \mathrm{~F}$ & $\mathrm{C}$ & 1 & $\mathrm{C}$ & & 13 & Mesalazine \\
\hline 24 & $9.9 \mathrm{M}$ & $\mathrm{C}$ & 1 & $\mathrm{C}$ & 6 & $<5$ & Prednisolone/mesalazine \\
\hline \multicolumn{8}{|c|}{ Indeterminate colitis } \\
\hline 25 & $10.9 \mathrm{M}$ & C & 3 & C & $<1$ & $<5$ & Prednisolone/mesalazine \\
\hline 26 & $10 \cdot 5 \mathrm{M}$ & C & 2 & C & 25 & 24 & Nil \\
\hline 27 & $7 \cdot 5 \mathrm{~F}$ & I & 2 & I,C & & 11 & Prednisolone \\
\hline \multicolumn{8}{|c|}{ Controls } \\
\hline 28 & $4 \cdot 4 \mathrm{M}$ & C & 0 & & & $<5$ & \\
\hline 29 & $3.9 \mathrm{M}$ & C & 0 & & 110 & 12 & \\
\hline 30 & $9.9 \mathrm{~F}$ & C & 0 & & 7 & 7 & \\
\hline 31 & $9.5 \mathrm{M}$ & C & 0 & & 18 & 23 & \\
\hline 32 & $0.6 \mathrm{~F}$ & C & 0 & & & & \\
\hline 33 & $7 \cdot 3 \mathrm{~F}$ & C & 0 & & 57 & & \\
\hline 34 & $8 \cdot 3 \mathrm{M}$ & C & 0 & & 8 & $<5$ & \\
\hline 35 & $10 \cdot 8 \mathrm{~F}$ & C & 0 & & 3 & $<5$ & \\
\hline 36 & $7 \cdot 1 \mathrm{~F}$ & $\mathrm{C}$ & 0 & & & $<5$ & \\
\hline 37 & $10 \cdot 3 \mathrm{~F}$ & C & 0 & & 6 & $<5$ & \\
\hline
\end{tabular}

$\mathrm{I}=$ ileum; $\mathrm{C}=$ colon; $\mathrm{CRP}=\mathrm{C}$-reactive protein; $\mathrm{ESR}=$ erythrocyte sedimentation rate.

distortion, goblet cell depletion, and villous atrophy. In patients with Crohn's disease the presence of granulomas did not necessarily influence the overall score.

This study received ethical approval from the Hackney and District Health Authority.

Cells were isolated from two biopsy specimens by collagenase digestion exactly as described elsewhere. ${ }^{13}$ Over $90 \%$ of the cells were viable by trypan blue exclusion. A median of $20 \%$ (range 16-24\%) of the cells were large, containing prominent organelles and occasionally a brush border could be seen; these were presumably epithelial cells. The remainder of the cells were mononuclear. Total cell yields (including epithelial cells) from the two biopsy specimens were $1.32 \times$ $10^{6}$ (range $0.9-1 \cdot 8$ ) for patients with Crohn's disease; $1.1 \times 10^{6}$ (range $0 \cdot 6-2 \cdot 0$ ) from the patients with ulcerative colitis; and $0.9 \times 10^{6}$ (range $0 \cdot 4-1 \cdot 2$ ) from the controls. An aliquot of the cells was used to make cytocentrifuge preparations so that the prevalence of $T$ cells could be determined by immunochemistry with $\mathrm{CD} 3$, as described elsewhere. ${ }^{13} \mathrm{CD} 3+$ cells were determined as a percentage of the total cells on the cytocentrifuge slide, including epithelial cells. The rest of the cells were used for the ELISPOT assay. Tests for each specimen were performed in duplicate.

For the ELISPOT assay, mucosal cells (20-25 000) were added to nitrocellulose-bottomed microwells coated with monoclonal anti-IL-4 antibody $(1.7 \mu \mathrm{g} / \mathrm{ml}$, Mabtech AB Stockholm, Sweden). After incubation for 20 hours, the cells were washed off and bound IL-4 revealed by adding a biotinylated, noncompeting, anti-IL-4 antibody $(2 \mu \mathrm{g} / \mathrm{ml}$, Mabtech $\mathrm{AB}$ ). These concentrations were shown to be optimal in preliminary experiments. Bound antibody was revealed by streptavidin conjugated alkaline phosphatase. These antibodies stain Chinese hamster ovary (CHO) cells transfected with the human IL-4 gene and do not show any cross-reactivity with other cytokines.

The number of spots were counted in each well and related to the number of $T$ cells added (calculated from the cytocentrifuge preparations). Results from duplicate wells were averaged. Variation between duplicates was usually less than $20 \%$. If variation was large, the experiment was considered a technical failure and the results from that patient discarded.

Data from each group were first analysed to determine if they conformed to a sample from a normally distributed population. In all cases they did. Comparisons between means were carried out using Student's $t$ test.

\section{Results}

There was a slightly higher percentage of $T$ cells in the cell suspensions isolated from children with inflammatory bowel disease than control children, but it did not reach significance because of the wide ranges (fig 1).

When the prevalence of IL-4 secreting cells per $10000 \mathrm{~T}$ cells was determined in control 


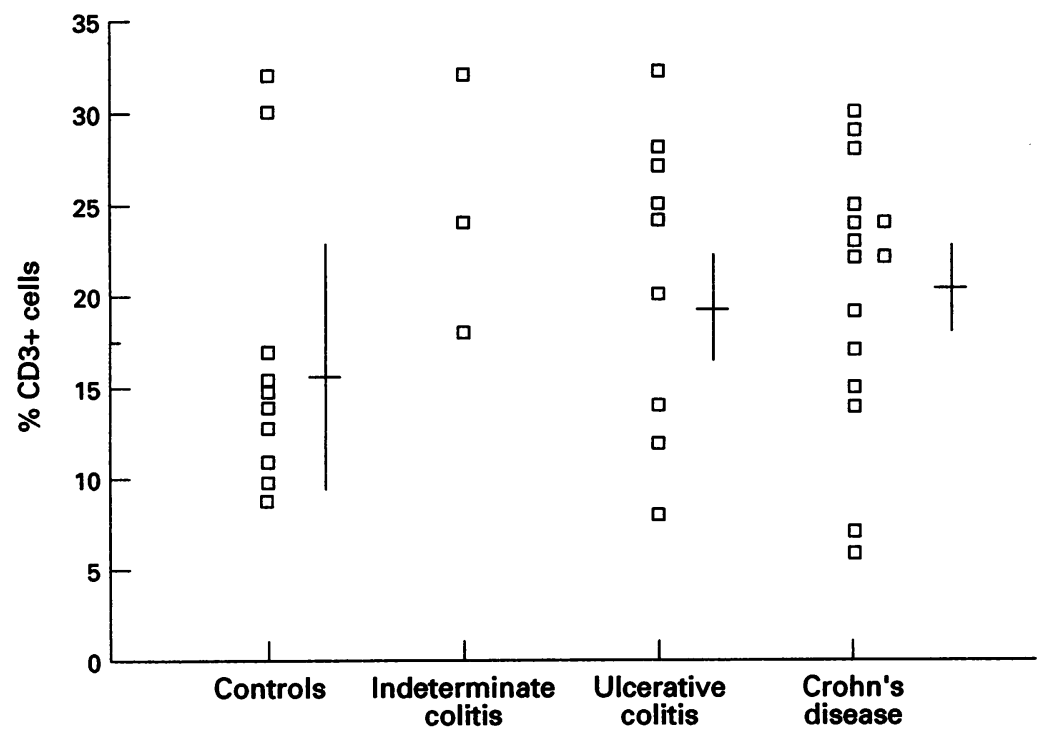

Figure 1 The percentage of $T$ cells (individual values and mean SD) isolated from intestinal biopsy specimens of control subjects and those with active Crohn's disease, indeterminate colitis, or ulcerative colitis.

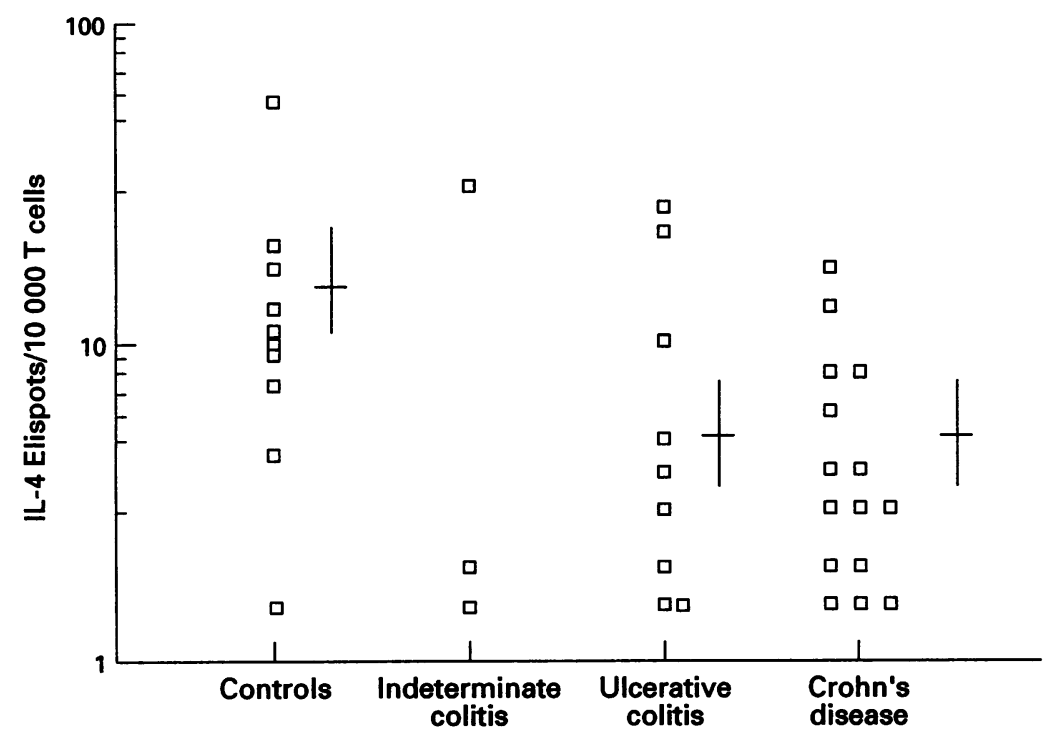

Figure 2 The number of IL-4 secreting cells per $10000 \mathrm{~T}$ cells (individual values and mean SD) in cells isolated from mucosal biopsy specimens of control patients and those with active Crohn's disease, indeterminate colitis, or ulcerative colitis (Crohn's $v$ control $p<$ 0.02 ; ulcerative colitis $v$ normal, $p<0.05$; Student's $t$ test).

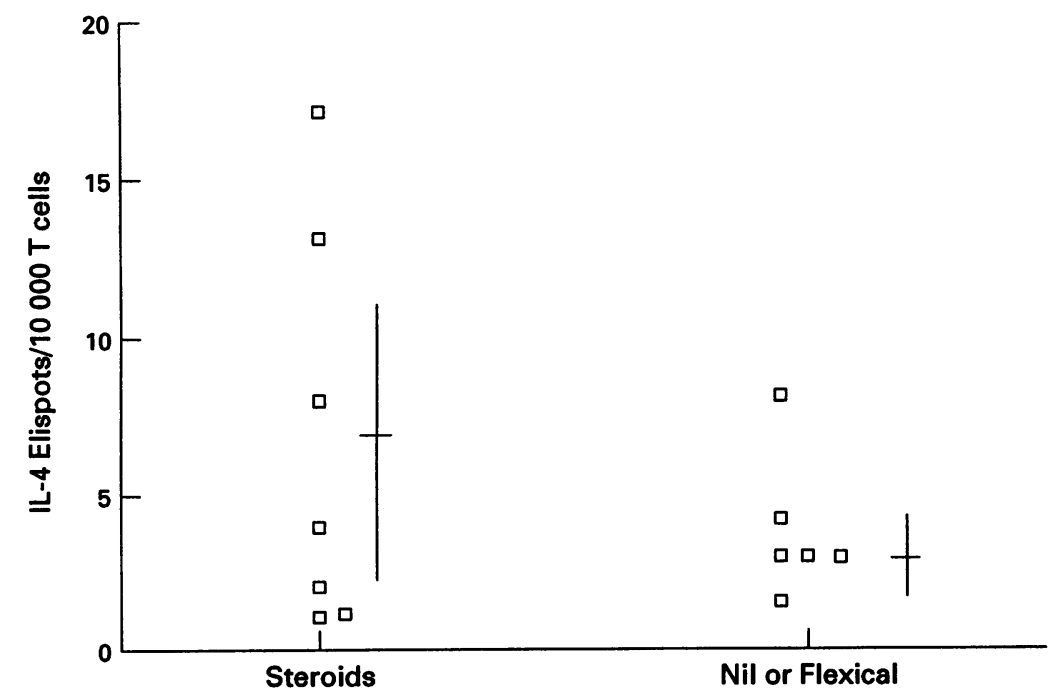

Figure 3 The effect of treatment modality on the loss of IL-4 secreting cells in Crohn's disease. Despite treatment all children had ongoing active inflammation. Each point represents an individual patient. children, a mean of 15 cells per $10^{4} \mathrm{~T}$ cells were secreting IL-4 (range two to 57). This was significantly reduced to around 5 cells per $10^{4} \mathrm{~T}$ cells in children with ulcerative colitis or Crohn's disease, although again there was a wide variation between individual patients. Two of three children with indeterminate colitis also had levels of 1 and 2 IL-4 secreting cells per $10^{4} \mathrm{~T}$ cells (fig 2 ).

There were enough children with active Crohn's disease to determine whether the reduction was related to steroid use or to the histological severity of the lesion. There was no difference in the prevalence of IL-4 secreting cells between children treated with steroids or those treated with enteral nutrition or no treatment (fig 3). The subgroup of four children with untreated Crohn's disease had low numbers of IL-4 secreting cells $(1,3,3,8$ per $10000 \mathrm{~T}$ cells). A single child treated with mesalazine alone also had low numbers of IL-4 secreting cells ( 2 per $10000 \mathrm{~T}$ cells). The children treated with steroids $(n=7)$ fell into two distinct subgroups, four with low levels $(1,1,2,4$ per $10000 \mathrm{~T}$ cells) and three with high levels $(8,13,17)$. Although the numbers in each group are small, there was no correlation with histological severity of disease, most patients having less than 5 IL-4 secreting cells per $10000 \mathrm{~T}$ cells (fig 4).

Because of small patient numbers, it was impossible to determine whether there were differences between patients treated with steroids alone, steroids plus mesalazine, or cyclosporin A.

Blood lymphocytes from three healthy donors were also studied and the prevalence of spontaneous IL-4 secreting cells was very low $(0 \cdot 2-0 \cdot 3$ cells per $10000 \mathrm{~T}$ cells).

\section{Discussion}

This study was carried out for two main reasons. First to determine whether in ulcerative colitis $\mathrm{T}$ cells were producing a Th2-type cytokine, such as IL-4, as we had already shown that, in contrast to Crohn's disease, IL-2 and interferon- $\gamma$ production was low in ulcerative colitis. ${ }^{3}$ The answer to this question is clear. There is no evidence for increased IL4 production in ulcerative colitis nor in Crohn's disease, thus further substantiating our notion that Crohn's disease is due to a Thl-type $T$ cell response in the gut mucosa. The second question was whether IL-4 is produced in the gut during inflammation, regardless of the disease. The answer to this question is again, clearly, that it is not. Thus, although IL-4 can have pro-inflammatory effects such as synergising with tumour necrosis factor $a(\mathrm{TNF} a)$ to increase endothelial vascular cell adhesion molecule (VCAM) expression, ${ }^{14}$ induce adherence of eosinophils and basophils to endothelium, ${ }^{15}$ and can synergise with interferon- $\gamma$ to increase secretory component expression by epithelial cells, ${ }^{16}$ this does not seem to be a major pathway in inflammatory bowel disease.

The major finding in this paper is that numbers of IL-4 secreting cells were reduced in the intestinal mucosa in Crohn's disease, ulcerative colitis, and in two of three patients 


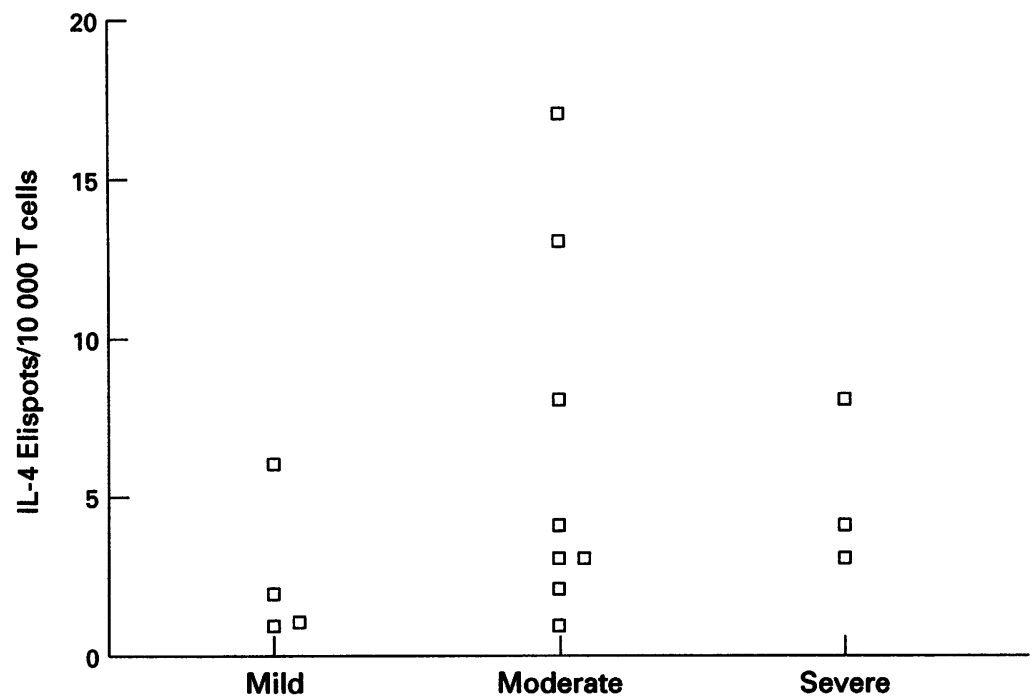

Figure 4 Correlation between the degree of reduction in IL-4 in active Crohn's disease and the degree of histological inflammation. Each point represents an individual patient.

with indeterminate colitis. Further studies on material from patients with coeliac disease and other enteropathies are needed to determine if this is a common feature of all gut inflammation. Normal mucosa contained around $15 \mathrm{IL}-4$ secreting cells per $10000 \mathrm{~T}$ cells. This number is rather low, but it fits in well with the results of previous studies. McCabe et $a l^{17}$ were only able to detect IL-4 transcripts in one of four intestinal mononuclear cell preparations from normal intestine. Interestingly, these workers were only able to detect IL-4 transcripts in one of three ulcerative colitis specimens and one of three Crohn's disease specimens, further confirming that IL-4 is not up-regulated in idiopathic inflammatory bowel disease.

Ongoing treatment of patients with Crohn's disease did not seem to increase the number of IL-4 secreting cells. However, it is interesting that in biopsy specimens taken from children with no treatment $(n=4)$ levels were low. In children treated with steroids two of the seven had normal numbers of IL-4 secreting cells. This might suggest that these two children were responding to treatment and that the mucosa was healing.

One obvious explanation for our results is that the mucosal IL-4 secreting cells were diluted out by non-IL-4 secreting $\mathrm{T}$ cells moving into the inflamed mucosa from the blood. However, without a phenotypic marker for the IL-4 secreting cells in the mucosa it is impossible to determine if this is the case.

The presence of IL-4 secreting cells in normal mucosa is likely to be due to the fact that many of these cells are derived from $T$ blasts, stimulated by antigen in the Peyer's patches, which then migrate to the mucosa. ${ }^{18}$ There is good evidence that mucosal $T$ cells are in a higher state of activation than blood $\mathrm{T}$ cells, ${ }^{19}$ and indeed, when we measured IL-4 production in unstimulated blood lymphocytes, we only obtained two to three secreting cells per $100000 \mathrm{~T}$ cells, about 70 times lower than with gut $T$ cells from healthy people. The main function of $\mathrm{IL}-4$ is in the promotion of IgE and IgG4 antibody secretion. ${ }^{2021}$ This, however, is unlikely to be the function of $\mathrm{IL}-4$ in the normal intestine because IgG plasma cells are rare and those of the IgG4 subclass particularly so. ${ }^{22}$

RK was supported by a grant from the Royal Society and TTM and EJB by the Wellcome Trust. This work was also supported by Crohn's in Childhood Research Association. We thank P Domizio for grading the histology.

1 Brynskov J, Tvede N. Plasma interleukin-2 and a soluble/shed interleukin-2 receptor in serum of patients with Crohn's disease. Effect of cyclosporin. Gut 1990; 31:795-9.

2 Choy M-Y, Richman PI, Walker-Smith JA, MacDonald TT. Differential expression of CD25 (Interleukin-2 receptor) on lamina propria $T$ cells and macrophages in the intestinal lesions in Crohn's disease and ulcerative colitis. Gut 1991;31:1365-70.

3 Breese EJ, Braegger CP, Corrigan CP, Walker-Smith JA, MacDonald TT. Interleukin-2- and interferon- $\gamma$-secreting $\mathrm{T}$ cells in normal and diseased human intestinal mucosa. Immunology 1993;78:127-31.

4 Fais S, Capobianchi MR, DiMarco P, Boirivant $M$, Dianzani F, Torsoli A. Spontaneous release of interferon gamma by intestinal lamina propria lymphocytes in Crohn's disease. Kinetics of in vitro response to interferon gamma inducers. Gut 1991;32:403-7.

5 Mullin GE, Lazenby AJ, Harris ML, Bayless TM, James SP. Increased interleukin-2 mRNA in the intestinal mucosal lesions of Crohn's disease but not ulcerative colitis. Gastroenterology 1992;102:1620-7.

6 Wallace JL, MacNaughton WK, Morris GP, Beck PL. Inhibition of leukotriene synthesis markedly accelerates healing in a rat model of inflammatory bowel disease. Gastroenterology 1989;96:29-36.

7 Yamada T, Sartor RB, Marshall S, Specian RD, Grisham MB. Mucosal injury and inflammation in a model of chronic granulomatous colitis in rats. Gastroenterology 1993;104:759-71.

8 Gurbindo C, Russo P, Sabbah S, Lohoues M-J, Seidman E. Interleukin-2 activity of colonic lamina propria mononuclear cells in a rat model of experimental colitis. Gastroenterology 1993;104:964-72.

9 Mosmann TR, Coffman RL. Heterogeneity of cytokine secreting patterns and functions of helper T cells. $A d v$ Immunol 1984;46:111-47.

10 Yamamura M. Defining protective responses to pathogens: cytokine profiles in leprosy lesions. Science 1991;254:277-9.

11 Quiding $M$, Nordstrom I, Kilander A, Andersson G, Hanson LA, Holmgren J, et al. Intestinal immune responses in humans. Oral cholera vaccination induces strong intestinal antibody responses and interferongamma production and evokes local immunological memory. $\mathscr{f}$ Clin Invest 1991;88:143-8.

12 Breese EJ, Michie CA, Nicholls SW, Murch SH, Williams $\mathrm{CB}$, Domizio $\mathrm{P}$, et al. Tumour necrosis factor-alpha producing cells in the intestinal mucosa of children with inflammatory bowel disease. Gastroenterology 1994;106: 1455-66.

13 MacDonald TT, Spencer J, Viney JL, Williams CB, Walker-Smith JA. Selective biopsy of human Peyer's patches during ileal endoscopy. Gastroenterology 1987; 93:1356-62.

14 Briscoe DM, Cotran RS, Pober JS. Effects of tumor necrosis factor, lipopolysaccharide, and IL -4 on the expression of vascular cell adhesion molecule-1 in vivo. Correlation with $\mathrm{CD} 3+\mathrm{T}$ cell infiltration. F Immunol 1992;149: 2954-60

15 Schleimer RP, Sterbinsky SA, Kaiser J, Bickel CA, Klunk $\mathrm{DA}$, Tomioka $\mathrm{K}$, et al. IL-4 induces adherence of human eosinophils and basophils but not neutrophils to endothelium. F Immunol 1992;148:1086-92.

16 Phillips JO, Everson MP, Moldoveanu Z, Lue C, Mestecky J. Synergistic effect of IL-4 and IFN- $\gamma$ on the expression of polymeric Ig receptor (secretory compoexpression of polymeric Ig receptor (secretory compo-
nent) and IgA binding by human epithelial cells. $\mathcal{F}$ nent) and IgA binding by

17 McCabe RP, Secrist H, Botney M, Egan M, Peters MG. Cytokine mRNA expression in intestine from normal and inflammatory bowel disease patients. Clin Immunol Immunopathol 1993;66:52-8.

18 Guy-Grand D, Griscelli C, Vassalli P. The mouse gut T lymphocyte, a novel type of $T$ cell. Nature, origin, and traffic in mice in normal and graft-versus-host conditions. F Exp Med 1978;148:1661-77.

19 Zeitz M, Green WC, Peffer NJ, James SJ. Lymphocytes isolated from the intestinal lamina propria of normal non-human primates have increased expression of genes associated with $T$ cell activation. Gastroenterology 1988 ; 94:647-54.

20 Lundgren M, Persson U, Larssosson P, Magnusson C, Smith CIE, Hammarstrom L, et al. Interleukin-4 induces synthesis of IgE and IgG4 in human B cells. Eur induces synthes $1989 ; 19: 1311-15$.

21 Gascan $\mathrm{H}$, Gauchat J-F, Roncarolo $M-G$, Yssel $H$, Gascan H, Gauchat J-F, Roncarolo M-G, Yssel H,
Spits H, de Vries JE. Human B cell clones can be induced Spits $\mathrm{H}$, de Vries JE. Human B cell clones can be induced
to proliferate and to switch to IgE and IgG4 synthesis by to proliferate and to switch to IgE and IgG4 synthesis by
interleukin-4 and a signal provided by activated CD $4+\mathrm{T}$ interleukin-4 and a signal provided by act
cell clones. $f$ Exp Med 1991;173:747-50.

22 Bjerke $K$, Brandtzaeg P. Terminally differentiated human intestinal B cells. IgA and IgG sub-class producing immunocytes in the distal ileum, including Peyer's patches, compared with lymph nodes and palatine tonsils. Scand F Immunol 1990;32:61-7. 